Elsi Utami Mayor, Setyowati, Tri Budiati

Penerapan Teori Konservasi Levine Pada Klien Kanker Ovarium

\title{
PENERAPAN TEORI KONSERVASI LEVINE PADA KLIEN KANKER OVARIUM
}

\author{
Elsi Utami Mayor ${ }^{1}$, Setyowati ${ }^{2}$, Tri Budiati ${ }^{3}$ \\ ${ }^{1)}$ RSUD Padang Panjang Sumatera Barat \\ ${ }^{2), 3)}$ Fakultas Ilmu Keperawatan Universitas Indonesia
}

Korespondensi penulis: fantasya_cici@yahoo.com

\begin{abstract}
Abstrak
Kanker ovarium merupakan salah satu penyakit pada perempuan dengan berbagai gejala sepanjang hidup. Gejala yang paling sering muncul adalah keletihan akibat perut membesar, asites, mual muntah dan asupan nutrisi yang tidak adekuat. Penerapan teori konservasi Levine dapat digunakan pada pasien dengan kanker ovarium yang bertujuan agar perawat dapat membantu perempuan dengan kanker ovarium melakukan konservasi menggunakan sumber daya yang dimilikinya dalam menghadapi penyakitnya, sehingga dapat beradaptasi dan mencapai keutuhan. Melalui konservasi energi, konservasi integritas struktur, konservasi integritas personal dan konservasi integritas sosial kelima perempuan dengan kanker ovarium dapat berespon secara adaptif dan mempertahankan keutuhannya. Hasil ini dapat digunakan untuk mengelola pasien dengan kanker ovarium pada area maternitas.
\end{abstract}

Kata kunci: kanker ovarium; konservasi; keutuhan

\section{PENDAHULUAN}

Kesehatan reproduksi merupakan parameter kemampuan negara dalam menyelenggarakan pelayanan kesehatan terhadap masyarakat. Derajat kesehatan perempuan terutama kesehatan reproduksi perlu menjadi perhatian, karena memiliki pengaruh besar terhadap kelanjutan generasi penerus suatu bangsa. Hal ini dapat dilakukan dengan meningkatkan kesehatan reproduksi perempuan yang memiliki dampak yang luas dan menyangkut berbagai aspek kehidupan (Lilyani, Sudiat \& Basuki, 2012).

Perawat spesialis maternitas berperan dalam meningkatkan kesehatan reproduksi pada perempuan. Peran perawat sebagai salah satu pemberi pelayanan keperawatan yang ikut aktif dalam memberikan perawatan pada kaum perempuan baik dalam tatanan klinik maupun komunitas.
Pendidikan keperawatan spesialis maternitas memiliki kompetensi agar residen mampu mensintesa berbagai teori keperawatan dan diaplikasikan pada pelayanan keperawatan. Pengkajian teori keperawatan dalam asuhan keperawatan menghasilkan suatu penanganan yang terperinci tentang intervensi dan modifikasi yang dilakukan sesuai kondisi pasien, Pengaplikasian teori keperawatan dapat dilakukan pada semua masalah kesehatan perempuan melalui keperawatan yang holistik dan komprehensif.

Salah satu permasalahan ginekologi yang paling banyak adalah tentang kanker ovarium. Kanker ovarium merupakan kanker yang berasal dari jaringan ovarium yang merupakan salah satu gangguan ginekologi yang paling sering dijumpai pada wanita di masa reproduksinya (Goh et al, 2007). 
Elsi Utami Mayor, Setyowati, Tri Budiati

Penerapan Teori Konservasi Levine Pada Klien Kanker Ovarium

The American Cancer Society memperkirakan bahwa pada tahun 2014, sekitar 21.980 kasus baru kanker ovarium akan di diagnosis dan 14.270 wanita akan meninggal karena kanker ovarium di Amerika Serikat (Carolyn, 2013). Angka kejadian penyakit kanker ovarium di Indonesia belum diketahui dengan pasti Gambaran kasus di RS Kanker Dharmais ditemukan kira-kira 30 penderita setiap tahun.

Nasdaldy (2009) mengatakan bahwa menurut data hasil penelitian di Rumah Sakit Umum Cipto Mangunkusumo terdata pada tahun 2008 terdapat 428 kasus penderita kanker ovarium, 20\% diantaranya meninggal dunia, sedangkan pada tahun 2009 terdata 768 kasus penderita kanker ovarium dan $25 \%$ diantaranya meninggal dunia (Oemiati, Rahajeng \& Kristanto, 2011).

Laporan dari Badan Registrasi Kanker Departemen Kesehatan Republik Indonesia yang diperoleh dari 13 Laboratorium Pusat Patologi Anatomi di Indonesia menunjukkan bahwa angka proporsi kanker ovarium di antara kanker pada wanita adalah 4,9\% (Lubis et al, 2013).

Perempuan dengan kanker ovarium akan mengalami berbagai gangguan dan memerlukan beberapa penatalaksanaan untuk mengatasi gangguan. Keluhan utama yang sering timbul pada stadium awal dari keganasan ovarium adalah perasaan berat dan tidak enak pada perut bagian bawah disertai nyeri, sering kencing dan konstipasi apabila massa menekan kandung kencing dan rectum (Gershenson \& Coleman, 2007).

Pasien dengan kanker ovarium memerlukan bantuan perawatan agar dapat mempertahankan keutuhan kehidupannya secara normal. Model konservasi Levine dapat membantu perawat melalui kerangka kerja yang mewakili pandangan individu secara holistik, aktif dan mandiri.
Prinsip Konservasi Levine terdiri dari konservasi energi, integritas struktur, integritas personal dan integritas sosial (Meffort, 2014). Hal ini merupakan dasar ners spesialis keperawatan maternitas dalam melakukan tindakan konservasi untuk memberikan pelayanan holistik pada pasien dengan kanker ovarium sehingga keutuhan dapat tercapai.

\section{METODE}

Metode yang digunakan adalah studi kasus dengan penerapan teori model konsep konservasi pada lima kasus perempuan dengan kanker ovarium sebelum dilakukan operasi yang telah dirawat minimal tiga hari. Tiga orang pasien dengan kanker stadium tiga dan dua orang pasien kanker stadium empat.

\section{HASIL}

Aplikasi teori konservasi Levine pada kelima kasus perempuan dengan kanker ovarium memberikan beberapa data dasar tentang karakteristik kelima pasien. Lima pasien kelolaan dengan kanker ovarium berumur umur 28-44 tahun.

Pada pasien kelolaan ditemukan pada umur usia reproduktif dan premenopause. Tiga orang dari pasien kelolaan merupakan satu orang belum menikah, dua orang belum memiliki anak dan belum pernah hamil.

Dua orang pasien memiliki riwayat penggunaan kontrasepsi suntik. Dua orang pasien kelolaan juga mempunyai riwayat keturunan keluarga dengan kanker.

Pengkajian konservasi Levine telah diaplikasikan oleh residen pada klien dengan kanker ovarium melalui pengkajian konservasi energi, konservasi integritas struktur, konservasi integritas personal, konservasi integritas sosial. Dari kelima kasus kelolaan residen, beberapa klien mempunyai kesamaan dan perbedaan. Kelima pasien kasus kelolaan ditemukan gejala yang sama seperti mual muntah, 
Elsi Utami Mayor, Setyowati, Tri Budiati

Penerapan Teori Konservasi Levine Pada Klien Kanker Ovarium

intake sulit, perut besar, asites, susah untuk beraktifitas.

Hasil dari pemeriksaan USG pada lima kasus kelolaan terdapat dua diantaranya sifatnya bilateral artinya kedua ovarium mengalami pembesaran, sedangkan tiga pasien tumor bersifat unilateral. Konsistensi tumor kelima kasus kelolaan tiga orang yang konsistensinya kistik dan dua orang konsistensinya solid. Gerakan tumor pada kelima kasus terbatas, adanya asites dan ada penonjolan pada kavum douglas. Kesimpulannya bahwa secara integritas struktur kelima pasien mengalami kanker ovarium yang mengarah pada keganasan.

Tingkat keganasan ini juga dapat dinilai dari RMI. Nilai RMI ini dapat dinilai dari status menopause, gambaran USG dan nilai $\mathrm{Ca}$ 125. Kelima pasien kasus kelolaan memiliki nilai RMI lebih dari 200.

Kelima kasus menunjukkan bahwa pasien mempunyai dukungan sosial yang baik terutama dari keluarga, namun salah satu pasien sudah bercerai dan sudah tidak memiliki orang tua dan anak, hanya saudaranya saja yang menungguinya.

Trophicognosis yang teridentifikasi pada kelima kasus kelolaan yaitu trophicognosis konservasi energi : keletihan berhubungan dengan asupan nutrisi in adekuat, mual muntah dan proses penyakit kanker, trophicognosis integritas structural Nyeri berhubungan dengan penekanan tumor pada saraf dan pada organ sekitar, dan intoleransi aktifitas berhubungan dengan perut yang membesar.

Lima pasien kasus kelolaan juga teridentifikasi gangguan pada Trophicognosis konservasi integritas personal kecemasan berhubungan dengan kondisi penyakit dan situasi kritis, perubahan peran berhubungan dengan ketidak mampuan dalam menjalankan peran, kurangnya pengetahuan tentang proses penyakit. Tiga orang pasien teridentifikasi masalah gangguan konservasi integritas personal disfungsi seksual berhubungan dengan kondisi penyakit, perut yang membesar.

Tindakan keperawatan dilakukan baik secara mandiri maupun kolaborasi. Tindakan keperawatan untuk mengatasi gangguan pada konservasi energi adalah manajemen energi yaitu dengan membantu klien untuk memahami prinsip konservasi energi, misalnya kebiasaan untk membatasi aktivitas, membantu klien memprioritaskan kegiatan untuk mengakomodasi kegiatan yang diperlukan, menganjurkan aktivitas fisik, seperti ambulasi, jalan-jalan, menganjurkan tidur siang. Membantu klien untuk mengatur jadwal istirahat. Mengonsulkan ahli gizi untuk meningkatkan asupan energi dari makanan. Menganjurkan keluarga untuk membawa makanan yang disukai klien, sementara klien dalam masa perawatan di RS. Membantu klien untuk mengakses program- program gizi komunitas pada perempuan dengan kanker ovarium. Memberikan informasi mengenai modifikasi diet, seperti manfaat untuk penyembuhan

Tindakan keperawatan untuk mengatasi gangguan integritas struktural adalah pastikan perawatan analgesik bagi pasien dilakukan dengan pemantauan ketat melalui pemberian analgetik, kolaborasi dengan tim medis dalam memberikan obat analgetik. Bantu klien dalam memilih posisi yang nyaman. berikan informasi mengenai nyeri, seperti penyebab, lama, antisipasi ketidaknyamanan akibat prosedur. Menganjurkan klien untuk memilih dan mengimplementasikan tindakan untuk mengontrol nyeri (farmakologi, nonfarmakologi, interpersonal). Mengajarkan tekhnik nonfarmakologi teknik pernafasan dalam dan teknik relaksasi (peace with cancer).

Pada kelima pasien kasus kelolaan berbeda cara mengatasi kecemasan. Pada satu orang pasien lebih menyukai diskusi 
Elsi Utami Mayor, Setyowati, Tri Budiati

Penerapan Teori Konservasi Levine Pada Klien Kanker Ovarium

tentang penyakitnya dan apa kemungkinankemungkinan yang akan terjadi pada dirinya. Pasien dua mengurangi kecemasan dengan teknik relaksasi yang diajarkan oleh perawat. Pada pasien ketiga kecemasan dapat berkurang dengan ditemani suaminya dan berbincang-bincang dengan pasien sesame kanker. Pada pasien keempat dan pasien kelima lebih memilih melakukan teknik relaksasi yang diajarkan perawat dan melakukan diskusi tentang penyakit yang dialaminya.

Masalah konfilk peran pada klien dapat diatasi dengan mendiskusikan antara klien dan keluarga dalam pembagian tugas peran dalam keluarga. Kesepakatan dalam pembagian peran bahwa urusan rumah tangga dibantu oleh suami dan anaknya. Kondisi klien dengan kanker ovarium tidak memungkinkan untuk menjalankan perannya secara penuh sehingga membutuhkan dukungan dari keluarga dalam mengambil alih sebagai peran yang tidak dapat dilakukan oleh klien.

Masalah disfungsi seksual yang terjadi pada tiga orang klien kasus kelolaan yang masih memiliki pasangan. Intervensi yang dapat diberikan yaitu memberikan informasi tentang pentingnya seksual, fungsi seksual, efek penyakit terhadap seksualitas, cara mengekspresikan kasih sayang dalam bentuk diskusi dengan klien dan pasangannya

Evaluasi dilakukan untuk mengetahui efektifitas implementasi yang dilakukan berdasarkan tujuan yang tercapai. Implementasi yang rata-rata dilakukan selama tiga hari. Masalah keletihan dapat diatasi pada hari ketiga.

Pada salah satu pasien masalah keletihan tidak dapat diatasi pada hari ketiga karena kondisi kesehatannya dan perutnya yang sangat besar dan asupan nutrisinya tidak adekuat.

Masalah gangguan nutrisi dapat diatasi pada hari ketiga dengan respon klien mampu meningkatkan asupan nutrisi dan mual muntah tidak terjadi. Masalah kecemasan dapat diatasi pada hari kedua setelah klien menerima informasi tentang penyakitnya dan prognosis serta pemberian edukasi secara psikososial dan spiritual mengenai masalah yang ditimbulkan akibat penyakitnya.

Masalah intoleransi aktifitas dapat diatasi pada hari ketiga setelah dilakukan peningkatan asupan nutrisi dan mengajarkan klien untuk mobilisasi secara bertahap dengan bantuan keluarga. Pada lima kasus kelolaan memberikan respon yang adapatif terhadap tindakan keperawatan yang diberikan dengan melakukan konservasi energi, integritas struktural dan integritas personal.

\section{PEMBAHASAN}

Pada pasien kelolaan dengan kanker ovarium ditemukan pada umur usia reproduktif dan premenopause. Tingginya angka kejadian kanker ovarium pada usia reproduksi berhubungan dengan aktivitas estrogen. Sekresi hormon estrogen oleh ovarium meningkat pada usia reproduksi. Secara keseluruhan insiden kanker ovarium meningkat seiring dengan bertambahnya usia (Aubard \& Poirot, 2013)

Hasil pengkajian pada kelima kasus kanker ovarium menunjukkan bahwa dua orang pasien merupakan ibu multipara, satu kasus belum menikah, dan dua kasus dengan infertilitas primer. Beberapa penelitian menunjukkan bahwa terdapat hubungan timbal balik antara paritas dengan terjadinya kanker ovarium Faktor resiko timbulnya kanker ovarium adalah nullipara dan wanita tanpa anak mempunyai dua kali resiko mendapat kanker ovarium karena berhubungan dengan periode jangka lama ovulasi berulang (NICE, 2011).

Pada pengkajian konservasi energi bahwa pada kelima pasien dengan kanker ovarium mengeluh kelemahan atau keletihan. Menurut NANDA (2015) kelemahan secara 
Elsi Utami Mayor, Setyowati, Tri Budiati

Penerapan Teori Konservasi Levine Pada Klien Kanker Ovarium

terus menerus dan penurunan kapasitas untuk melakukan aktivitas fisik dan mental pada tingkatan tertentu. Kondisi ini dapat mempengaruhi kemampuan pasien dalam melakukan manajemen diri terhadap gejala, sehingga pencapaian status kesehatan pasien tidak berjalan secara maksimal.

Pada kelima pasien dengan kanker ovarium didapatkan pengkajian integritas struktur perempuan dengan kanker ovarium ditemukan keluhan nyeri ringan sampai sedang. Nyeri ini disebabkan oleh putaran tangkai terjadi pada tumor bertangkai dengan diameter lima sentimeter atau lebih yang menimbulkan tarikan melalui ligamentum infundibulopelvikum terhadap peritoneum parietal dan ini menimbulkan rasa sakit (Hamilton, 2009).

Gangguan konservasi integritas personal pada klien dengan kanker ovarium pada kelima kasus kelolaan menunjukkan bahwa semua pasien mengalami kecemasan. Individu pengidap kanker akan mengalami dampak psikologis dari diagnosis kankernya. Efek samping perubahan tubuh akibat tumor juga mengakibatkan perubahan gambaran diri penderita, yang menyebabkan stress dan kecemasan (Falvo, 2005). Sebagian individu penderita kanker, termasuk penderita kanker ovarium, bereaksi sangat besar saat pertama kali mengetahui diagnosanya. Sehingga penderita kanker ovarium mengalami kondisi psikologis yang sama dengan kanker ovarium. Reaksi ini meliputi depresi, takut, penarikan diri, kemarahan dan penyangkalan. Seiring berjalannya waktu, mereka mulai dapat menerima keadaan dan berusaha melakukan adaptasi apapun yang diperlukan untuk menjalankan hidup (Falvo, 2005).

Tiga orang dari pasien kelolaan merupakan satu orang belum menikah, dua orang belum memiliki anak dan belum pernah hamil. Hal ini dapat menimbulkan kecemasan pada pasien. Wanita yang belum menikah, masih muda, dan belum memiliki anak, apabila terkena kanker ovarium, pasti akan takut tidak bisa memiliki keturunan karena suatu hambatan dalam produksi sel telur mereka. Apabila penderita merasa cemas dan takut maka akan mengganggu keadaan psikis atau mentalnya (Salim, 2013). Kondisi ini akan mempengaruhi bagaimana penerimaan diri individu tersebut.

Sarafino \& Smith (2011) menyatakan terdapat lima tahapan reaksi psikologis pasien penderita penyakit kronis, yaitu penyangkalan, kemarahan, tawar-menawar depresi dan penerimaan. Ceyhan (2010) menyebutkan bahwa penerimaan diri adalah indikator penting bagi kesehatan mental. Penerimaan diri ini dibutuhkan pada penderita kanker ovarium, agar penderita tidak hanya mengakui keterbatasan yang dimilikinya tetapi juga mempergunakan berbagai potensi yang dimilikinya agar dapat meningkatkan kepercayaan diri sehingga membantu proses pengobatannya (Dodge et al, 2012).

Tindakan khusus yang diberikan kepada lima pasien dari tindakan keperawatan kepada pasien yaitu melakukan breathing exercise untuk mengatasi keletihan. Breathing exercise merupakan teknik penyembuhan yang alami untuk mengatasi keletihan, nyeri, stres, dan kecemasan. Breathing exercise dapat menstimulasi sistem saraf parasimpatik sehingga meningkatkan endorpin, menurunkan nadi, memaksimalkan ekspansi paru sehingga terjadi relaksasi otot. Teknik ini juga dapat meningkatkan suplai oksigen dalam tubuh (Stanley, 2011).

Selain itu juga dilakukan teknik relaksasi "peace with cancer" yang merupakan suatu upaya untuk mencapai kondisi yang tenang, dan nyaman dengan pemberdayaan energi bawah sadar seseorang, mengistirahatkan energi sadar melalui afirmasi atau sugesti 
Elsi Utami Mayor, Setyowati, Tri Budiati

Penerapan Teori Konservasi Levine Pada Klien Kanker Ovarium

positif kepada klien dengan menggunakan kata-kata (Sunardi 2009).

Hasil dari tindakan relaksasi yang diberikan dapat mengatasi gangguan pada konservasi energi, konservasi intergritas struktural dan intergritas personal. Hal ini ditunjukkan dengan tanda-tanda vital dalam batas normal setelah dilakukan teknik relaksasi, nyeri dapat berkurang, kecemasan berkurang, dan mual muntah juga dapat diatasi.

Model keperawatan konservasi Levine sangat aplikatif dalam perawatan perempuan dengan kanker ovarium melalui tahap pengkajian lingkungan internal dan eksternal. Pengkajian terasa lebih mudah dan lebih fokus. Pada tahap konservasi terlihat kebutuhan apa yang diperlukan saat ini oleh pasien baik itu konservasi energi, struktural, dan personal dan sosial.

Pada kasus perempuan dengan kanker ovarium menimbulkan gejala-gejala ketidaknyaman yang menimbulkan gangguan untuk keseimbangan dari energi. Menggunakan teori Levine membuat perawat mampu melakukan tindakan yang sistematis dan fokus pada konservasi yang terganggu sehingga dapat mencegah terjadinya integritas struktur dan tercapainya adaptasi yang merupakan tujuan utama dari konsep konservasi Levine.

\section{KESIMPULAN}

Pasien dengan kanker ovarium mengalami perubahan dan mengalami gejala-gejala ketidaknyamanan akibat penyakitnya. Model konservasi levine digunakan untuk asuhan keperawatan. Perubahan yang dialami pasien dengan kanker ovarium meliputi aspek konservasi energi, integritas structural, personal dan sosial. Perubahan yang dialami oleh kasus kelolaan seperti perubahan bentuk tubuh seperti perut membesar, mual, muntah, kurang nafsu makan dan susah untuk mobilisasi serta gangguan psikologis, seksual dan peran.

Masalah yang dialami oleh kelima pasien kasus kelolaan adalah trophicognosis konservasi energi yaitu keletihan, trophicognosis konservasi integritas struktural yaitu nyeri dan intoleransi aktifitas, trophicognosis konervasi integritas personal yaitu kecemasan, perubahan peran dan disfungsi seksual.

Implikasi keperawatan yang bisa dilakukan pada pasien dengan kanker ovarium sebelum dilakukan operasi menggunakan model konservasi Levine adalah memfasilitasi pasien dalam beradaptasi terhadap gejala yang muncul memberikan dampak positif terhadap kualitas hidup pasien dengan kanker ovarium. Adanya pemberian informasi melalui pendampingan, edukasi, dan konseling dapat meningkatkan status emosional pasien dan dapat mengaktifkan mekanisme koping efektif bagi pasien dalam menghadapi stressor baik fisik maupun psikologis yang diakibatkan oleh proses perjalanan penyakit.

\section{DAFTAR PUSTAKA}

Andersen, M.R., Sweet, E., Lowe, K.A., Standish, L.J., Drescher, C.W., Goff, B.A., (2012). Involvement in decisionmaking about treatment and ovarian cancer survivor quality of life. Gynecologic Oncology 124 (3), 465e470.

Billson, H.A., Holland,C., Curwell, J., Davey,V.L., Kinsey, L., Lawton L.J., \& Whitworth , A.J. (2013). Perioperative nutrition interventions for women with ovarian cancer. Cochrane Database of Systematic Reviews, 9. doi: 10.1002/14651858.CD009884.pub2. cancers. Archives of Gynaecology and Obstetrics 285 (6), $1713 \mathrm{e} 1717$.

Carolyn, R. (2013). Ovarian cancer: risk factors, treatment and management. 
Elsi Utami Mayor, Setyowati, Tri Budiati

Penerapan Teori Konservasi Levine Pada Klien Kanker Ovarium

British Journal of Nursing, Oncology Supplement, 22, 17.

Ceyhan, A.A \& Ceyhan, E. (2010). Investigation of university students' selfacceptance and learned resourcefulness: a longitudinal study. High Educ, 61, 649661.

Dodge, J.E., Covens, A.L., \& Lacchetti, C. (2012). Management of a suspicious adnexal mass: a clinical practice guideline. Curr Oncol,19, e244-57

Franse, L.V., Nicolaije, K.A.H., …\& Pijnenborg, J.M. (2011).The impact of a cancer Survivorship Care Plan on gynecological cancer patient and health care provider reported outcomes (ROGY Care): study protocol for a pragmatic cluster randomized controlled trial. Trials Journal, 12(256).

Gershenson, D.M., Coleman, R.L.(2007). Neoplastic disease of the ovary: Screening, benign and malignant epithelial and germ cell neoplasms, sexcord stromal tumors. Dalam: Katz, V.L, Lentz G.M., Lobo, R. A., Gershenson, D. M., penyunting. Comprehensive Gynecology. Edisi ke-5. Philadelphia: Mosby Elsevier.

Goff ,B.A., Mandel, L.S., \& Drescher, C. W. (2007). Development of an ovarian cancer symptom index: possibilities for early detection. Cancer 109(2), 221-227.

Goh, J. Yam, S. F. Loh, A. Wong . (2007). Minimal access approach to the management of large ovarian Cysts. Surg Endosc 21, 80-83. doi: 10.1007/s00464005-0596-5.

Golbasi, Z., Erenel, A.S., 2012. The quality of sexual life in women with gynaecological.

Hwang, K.H., Cho, O.H., Yoo, Y.S. (2016). The Effect of Comprehensive Care Program for Ovarian Cancer Survivors.Clinical Nursing Research,25(2), 192- 208.
Lubis, N. D., Nizar, R. Z., Musa, Z.(2013). Kanker di Indonesia: data histopatologi. Jakarta: Direktorat Jendral Pelayanan Medik Departemen Kesehatan RI.

Oemiati, R., Rahajeng, E., Antonius Y. K. (2011). Prevalensi tumor dan beberapa faktor yang mempengaruhinya di Indonesia. Badan Penelitian dan Pengembangan Kesehatan, 39,4 